Warehouse design and control : framework and literature review

B. Rouwenhorst, R.J. Mantel,

B. Reuter, V. Stockrahm, G.J. van Houtum, and W.H.M. Zijm

WF 35

\begin{tabular}{rl|}
\hline BETA publicatie & WP 35 (working \\
& paper) \\
ISBN & $90-386-0869-1$ \\
ISSN & $1386-9213$ \\
NUGI & 684 \\
Eindhoven & Februari 1999 \\
Keywords & Survey; Warehouse; \\
& Design; Performance \\
& analysis \\
& Unit management \\
BETA-Research Programme & - \\
Te publiceren in: & \\
&
\end{tabular}




\title{
Warehouse Design and Control: Framework and Literature Review
}

\author{
B. Rouwenhorst; R.J. Mantel; B. Reuter \\ V. Stockrahm ${ }^{\ddagger}$, G.J. van Houtum; and W.H.M. Zijm \\ December 1998
}

\begin{abstract}
In this paper we present a reforence framework and a classification of warchouse clesign and control problems. Based on this framework, we review the cxisting litcrature on warchousing systems and indicate important gaps. In particular, we emphasize the need for design oriented studies, as opposed to the strong analysis oriented research on isolated subproblems that scons to be dominant in tho current literature.
\end{abstract}

Keywords: Survey, warchouso, dosign, performanco analysis.

* Corresponding author. Mailing address: Faculty of Mechanical Engineoring, University of Twente, P.O. Box 217, 7500 AE Enschede, Netherlands, Email: b.rouwenlorstowb.utwente.nl, Homepage ht.tp://www.opm.wb.utwente.nl/staff/bart/

tUniversity of Twente, Faculty of Mochanical Enginecring, Nethorlands

${ }^{\ddagger}$ Darmstadt University of Techuology, Dept. Fertigungs- und Materialwirtschaft, Germany

Eindhoven University of Technology, Faculty of Technology Management, Netherlands 


\section{Introduction}

The ever increasing trend towards more product variety and short response times has placed a tremendous emphasis on the ability to establish smooth and efficient logistic operations. These operations even play a vital role in determining a company's competitiveness, since logistic costs constitute an important part of the overall production costs. The efficiency and effectiveness in any distribution network in turn is largely determined by the operation of the nodes in such a network, i.e. the warehouses. Indeed, the innovations in warehouse technology are numerous during the last decade. With respect to warehouse management, topics like planning and control have deserved wide attention in both the popular and scientific literature, see e.g. van den Berg [11] and the references therein. In contrast, a sound theoretical basis for a warehouse design methodology still seems to be lacking.

The logistic costs that are made inside a warehouse are to a large extent already determined during the design phase. Typically, a design runs from a functional description, through a technical specification, to equipment selection and determination of a layout. In each stage, target performance criteria (costs, throughput, storage capacity, response times) have to be met. As such, warehouse design is a highly complex task, where in each stage trade-offs have to be made between often conflicting objectives. Another difficulty is the large number of feasible designs. Up to now, no overall accepted systematic procedure exists to design warehouses. Therefore, there is a clear need for research that can support such a systematic design approach.

This paper is meant to provide a framework for warehouse design and to review the literature while using this framework as a reference model. Within this paper, we restrict ourselves to topics concerning the internal warehouse structure and operations. Topics like economic justification of warehouses, the warehouse location problem and external logistics are not addressed. Also, human resource management and quality control are excluded.

In this paper we analyze problems that are encountered during the (re)design of a warehouse or a warehouse subsystem. Based on these analyses, we review the existing literature on warehouse design and control. We determine clusters of publications concerning specific problems as well as open areas for future research. An important drawback concerns the fact that the overwhelming majority of scientific papers address well-defined isolated problems and are typically of an analytical nature (performance analysis, evaluation of control policies, etc.). A 
design oriented approach on the other hand primarily aims at a synthesis of a large number of both technical systems and planning and control procedures. Since most problems encountered during warehouse design are unfortunately not welldefined and often can not be reduced to multiple isolated subproblems, design often requires a mixture of analytical skills and creativity. Anyhow, research aiming at an integration of various models and methods is badly needed in order to develop a methodology for systematic warehouse design.

The paper is organized as follows. In Section 2, we define three different axes along which warehouses may be viewed upon: processes, resources, and organization. In Section 3 we discuss performance criteria as well as the process of warehouse design on a strategic, tactical and operational level. Section 4 discusses the most important problems encountered on each of these three levels. Based on this framework, we review in Section 5 the existing literature on warehouse design and control. In addition, we point out important areas that have received relatively little attention so far and emphasize the need for more design oriented research (Section 6). Finally, in Section 7, we conclude the paper.

\section{Warehouse Characterizations}

In order to provide a characterization, this section discusses three different angles from which a warehouse may be viewed: processes, resources, and organization. Products arriving at a warehouse subsequently are taken through a number of steps called processes. Resources refer to all means, equipment and persommel needed to operate a warehouse. Finally, organization includes all planning and control procedures used to run the system.

Some definitions are needed for clarity. A product is defined as a type of good, for example shampoo bottles of a specific brand. The individual bottles are called items (or Stock Keeping Units, SKU's) and the combination of several items of several products that are requested by a customer is called a customer order.

\subsection{Warehouse Processes}

The flow of items through the warehouse can be divided in several distinct phases, or processes.

- The receiving process is the first process encountered by an arriving item. Products arrive by truck or internal transport (in case of a production warehouse). At this step, the products may be checked or transformed (e.g., 
repacked into different storage modules) and wait for transportation to the next process.

- In the storage process items are placed in storage locations. The storage area may consist of two parts: the reserve area, where products are stored in the most economical way (bulk storage area) and the forward area where products are stored for easy retrieval by an orderpicker. Products in the forward area are often stored in smaller amounts in easily to access storage modules. For example, the reserve storage may consist of pallet racks while the forward storage may consist of shelves. The transfer of items from the reserve storage to the forward storage is called a replenishment.

- Orderpicking refers to the retrieval of items from their storage locations and can be performed manually or (partly) automated. In succession, these items may be transported to the sorting-and/or consolidation process. Consolidation here refers to the grouping of items destined for the same customer.

- At the shipping area, orders are checked, packed and eventually loaded in trucks, trains or any other carrier.

\subsection{Warehouse Resources}

A number of resources can be distinguished (see also Frazelle [41] for an extensive review):

- The storage unit, in (or on) which products may be stored. Examples of storage units are pallets, carton boxes and plastic boxes.

- The storage system. This may consist of multiple subsystems that store different types of products. Storage systems are very diverse; they may range from simple shelves up to highly automated systems, containing automated cranes and conveyors.

- The retrieval of items from the storage system can be performed manually or by means of pick equipment. An example of often used pick equipment is a reach truck.

- Other equipment that supports the orderpicker are called orderpick auxiliaries, for example bar code scanners. 
- A computer system may be present to enable computer control of the processes by a warehouse management system.

- The material handling equipment for preparation of the retrieved items for the expedition includes sorter systems, palletizers and truck loaders.

- Finally, personnel constitutes an important resource, since warehouse performance largely depends on their availability.

\subsection{Warehouse Organization}

In this subsection, we discuss organizational issues in a warehouse.

- The far most important decision concerns the definition of the process flow at the design stage. Examples include: the decision to use a separate reserve area since this implies that a replenishment process will be part of the warehouse operation, the retrieval of items in batches or the splitting of the pick area in zones which both require a sorting process and/or a consolidation process, or the use of separate storage and retrieval aisles.

Furthermore, some processes require specific organizational policies:

- At the receiving process, an assignment policy determines the allocation of trucks to docks.

- At the storage process, items are transported to the storage system and are allocated to storage locations. Several storage policies exist. A dedicated storage policy prescribes a particular location for each product to be stored, whereas a random storage policy leaves the decision to the operator. In between, a class based storage policy ( $\mathrm{ABC}$ zoning) allocates zones to specific product groups, often based upon their turnover rate. Other storage policies include correlated storage or fumily grouping, aimed at storing products at nearby positions if they are often required simultaneously. If the storage system has a separate reserve area, a storage policy for the reserve area is also needed. Which articles in what quantity are stored in the forward area and how replenishments are timed, is decided by forward/reserve and replenishment policies, respectively. Note that the latter control problems highly depend on decisions made already at the design stage. 
- At the orderpicking process, (parts of) orders are assigned to one or more orderpickers. Various control problems deserve attention here. First, the total pick area may be divided into picking zones, to be served by different orderpickers, through a zoning policy. Two alternative policies exist: parallel or sequential zoning. Second, orders are picked one by one (single order picking) or in batches (batch picking). If a batch picking policy is selected, this directly implies that the picked orders must be sorted. Again, two sorting policies exist: pick and sort (sequentially) and sort while pick (simultaneously). Third, a routing policy may define the sequence of retrievals and the route to visit the retrieval locations. Finally, a dwell point policy may prescribe the position of idle orderpick equipment.

- If a consolidation and sorting process is present, orders are allocated to output lanes by an sorter lane assignment policy.

- At the shipping process, orders and trucks are allocated to docks by a dock assignment policy.

- Finally, allocation of tasks to personnel and equipment are addressed by operator and equipment assignment policies.

\section{Warehouse Design}

From the preceding section it becomes clear that the design of a warehouse system concens a large number of interrelated decisions. In this section we attempt to structure these decisions in a hierarchical framework. In addition, we discuss a number of performance criteria that serve to evaluate alternative designs.

\subsection{Warehouse Design Methods}

As mentioned already in Section 1, a design process typically runs through a number of consecutive phases: concept, data acquisition, functional specification, technical specification, selection of means and equipment, layout, and selection of planning and control policies. Alternatively, these decisions may be situated at a strategic, tactical or operational level. For instance, decisions concerning the process flow and the level of automation typically belong to the functional and partly technical specification and are of a strategic nature. Also the selection of basic storage systems is a strategic one, whereas the dimensioning of these systems 
and the determination of a layout are tactical decisions. Detailed control policies typically belong to the operational level. The conceptual and data acquisition phase as well as the implementation phase are beyond the scope of this paper and therefore excluded. Obviously, most decisions are interrelated but the hierarchical framework outlined above reflects the horizon of the decisions (long term, medium term, short term) while solutions chosen at a higher level provide the constraints for lower level design problems.

Starting with limited detail, a rough first design is outlined while at subsequent stages this design is refined. This is also known as the top-down approach, as opposed to the bottom-up approach. The ideal design method clusters related problems at the same design level and derives a solution by simultaneously optimizing the various subproblems in order to reach a global optimum. It is important to recognize the relations between subproblems, in order to avoid suboptimal solutions.

\subsection{Warehouse Performance Criteria}

In order to evaluate a particular warehouse design, clearly defined performance criteria are needed. Within the field of warehousing we distinguish the following criteria: investment and operational costs, volume and mix flexibility, throughput, storage capacity, response time, and order fulfillment quality (accuracy). In this section we will discuss some criteria in more detail and relate them to the various design levels and to different environments.

The relative importance of a particular criterion varies with the types of warehouses. Two types can be distinguished: the distribution warehouse and the production warehouse.

The function of a distribution warehouse is to store products and to fulfill external customer orders typically composed of a large number of order lines (where each order line specifies a quantity of one particular product). The number of different products in a distribution warehouse may be large, while the quantities per order line may be small, which often results in a complex and relatively costly orderpicking process. Therefore, distribution warehouses are often optimized for cost-efficient orderpicking. The prominent design criterion is the maximum throughput, to be reached at minimum investment and operational costs. These two cost parameters are often combined in a single cost performance criterion. The NPV (Net Present Value) represents the value of the investment at the present time. Costs and profits that are planned in the future are discounted. 
The ROI (Return On Investment) is another cost performance criterion, defining the expected profit per year, divided by the investment costs. These criteria are taken into account primarily at the strategic and tactical decision levels. Often, the combination of a desired throughput and a required short response time rules out already a number of technical solutions and indicates the use of more automated systems. A typical example of a warehouse system, suitable for a distribution warehouse, is an A-frame, a highly automated but costly orderpicking system.

The function of a production warehouse is to store raw materials, work-inprocess and finished products, associated with a manufacturing and/or assembly process. Raw materials and finished products may be stored for long periods. This occurs for example when the procurement batch of incoming parts is much larger than the production batch, or when the production batch exceeds the customer order quantity of finished products. Storage of goods for long periods must be costefficient and is usually done in large quantities in an inexpensive storage system, such as a palletrack. The prominent design criterion is the storage capacity. The main design objectives are low investment costs and operational costs. The storage of work-in-process has other requirements, since the demand is mostly unknown in advance and the retrieval from the warehouse must be fast, in order to avoid delay in the production. This may lead to a design constraint with respect to the time between an order request and its completion, the response time.

Performance criteria can be handled as either a design objective or a design constraint. When formulating a criterion as a constraint, we request that a prespecified target value of the criterion has to be met. In addition to constraints, related to these target criterion values, a number of technical or physical or even safety constraints are formulated. An example of the latter is the maximum height of a storage system in order to fit in a specific building. Investment costs are often treated as a constraint. A severe limitation on the investment costs may lead to a conventional warehouse design.

Finally, other performance criteria may be difficult to quantify, such as environmental or ergonomic conditions. These conditions will not be discussed further in this paper.

\section{Warehouse Design Problems}

In Section 2, we provided three views on warehouse operations, and in Section 3 we defined warehouse design as a structured approach of decision making at a 
strategic, tactical and operational level, in an attempt to meet a number of welldefined performance criteria. At each level, multiple decisions are interrelated and therefore it is often necessary to cluster relevant problems that are to be solved simultaneously. We define a warehouse design problem to be such a coherent cluster of decisions and we define decisions to be coherent when a sequential. optimization does not guarantee a globally optimal solution.

This section discusses problems arising at the various design levels. For each level, the problems are placed in perspective using the three axes defined in Section 2: processes, resources and organization.

\subsection{Strategic Level}

At the strategic level we consider decisions that have a long term impact, mostly decisions that concern high investments. The two main groups are the decisions concerning the design of the process flow and the decisions concerning the selection of the types of warehousing systems.

The process flow design defines the required processes. A basic flow consists of the stages receiving, storage, orderpicking, and shipment. Additional processes may be included which have an immediate impact on the selection of techical means and equipment. For example, a sorting process may be needed in order to batch and sort orders, requiring a sorter system. The inclusion of a forward/reserve replenishment system requires the presence of a bulk storage and an orderpick area.

The selections of the warehouse system types at the strategic level concern all systems that require a high investment like the storage system and the sorting system. As we have seen, the selection of processes requires the availability of specific systems but the reverse statement is also true. For example, a sorting process may only be selected if a sorter system exists that is capable to handle the products. Hence the two groups of decisions are interrelated. However, the complete selection process can be decomposed into two sequential decision problems: one based upon technical capabilities and the other one based on economic considerations.

The first problem concems technical capabilities. The storage unit, the storage systems and the equipment have to be suitable for the products, suitable for the orders, and should not conflict with each other. This warehouse design problem concerns both the design of the process flow and the selection of the main warehouse system types. The input for this problem are the characteristics of the 
products and the orders. The output of this design problem specifies which combinations of systems are technically capable of handling the products and meeting the performance constraints. Hence, the outcome is not a specified system, or even a small number of alternatives, but a, hopefully limited, number of possible combinations of warehouse systems that fulfills the technical and performance requirements (in particular throughput, response times and storage capacity).

The second warehouse design problem concerns the design of the process flow and the selection of warehouse systems based upon economic considerations. This results in an optimization over the range of possible system combinations selected in the preceding phase, aiming at minimum investment and operational costs.

The following observations can be made concerning the relations between several decisions:

- The warehouse investment costs are mainly determined by the (number of) resources.

- The warehouse storage capacity is mainly determined by the type and dimensions of the storage system. Of minor importance is the storage policy (dedicated storage, class-based storage or random storage).

- The maximum warehouse throughput is partly determined by the type and dimensions of the resources. A large number of other factors may also influence the maximum throughput: the separate reserve area decision, the storage policy, the batch policy, the routing policy and assignment policies (persomel, equipment and docks).

- The warehouse response time is partly determined by the factors related to the maximum throughput. However, it is also influenced by a number of other organizational decisions, such as the zoning policy, the sorting policy and the dwell point policy.

These observations once again underline the strong interrelationship between various decision problems at the strategic level. Ideally, these problems therefore should be grouped into one simultaneous decision problem. For practical reasons some decomposition seems unavoidable but it remains extremely important to explicitly model the relationships in any possible decomposition.

Figure 4.1 lists a number of design problems at the strategic level, related to the three axes defined in Section 2 (see also Mantel and Rouwenhorst [80]). All the decision problems in the shaded area are related. Recall that each individual 
decision on this level puts a constraint and additional requirements at decisions on lower levels. For instance, the strategic decision to use a separate reserve area implies that, at the tactical level, this reserve area is to be dimensioned, and that, at the operational level, replenishment policies have to be defined.

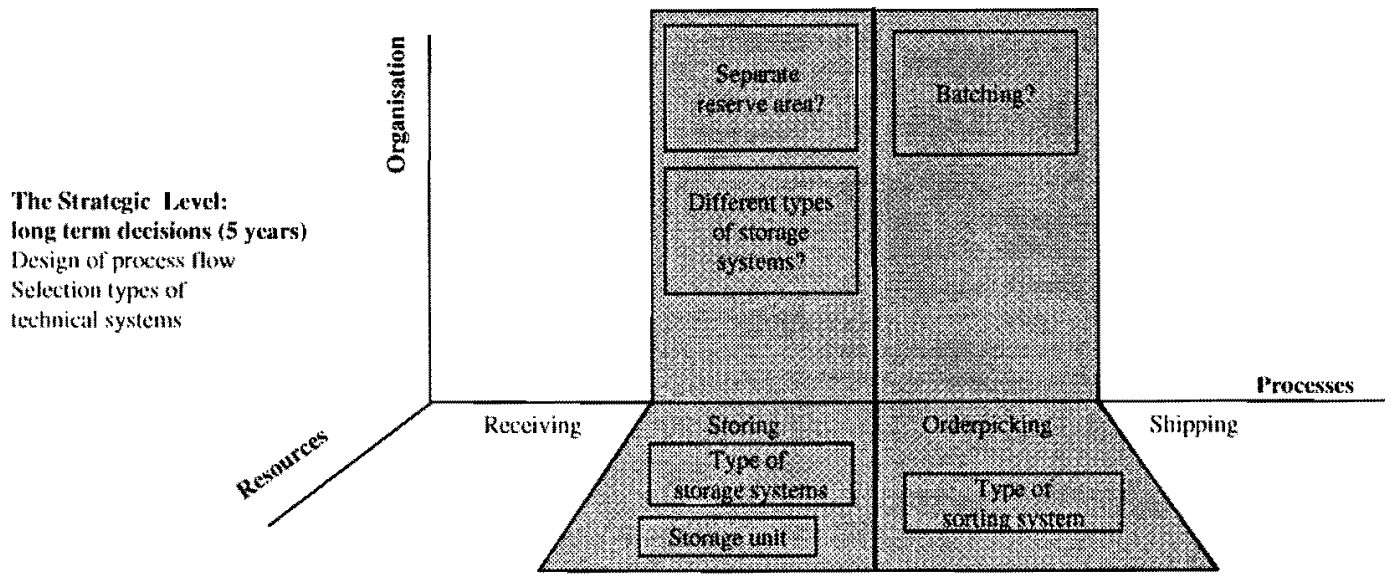

Figure 4.1: The Strategic Level.

\subsection{Tactical Level}

On the tactical design level, a number of medium term decisions are to be made, based on the outcomes of the strategic decisions discussed in the preceding subsection. The tactical decisions have a lower impact than the strategic decisions, but still require some investments and should therefore not be reconsidered too often. Tactical decisions typically concern the dimensions of resources (storage system sizes but also number of employees), the determination of a layout and a. number of organizational issues.

Clusters of problems that arise at the tactical level and should be treated simultaneously include:

- organizational problems including the dimensioning of the picking zones and the $\mathrm{ABC}$ zones, the determination of replenishment policies and batch sizes, and the selection of a storage concept (random, dedicated, class-based),

- determining the dimensions of the storage systems, including the forward and reserve areas, 
The Tactical level: mediam fern decisions ( 2 years) Dimensioning of the storage sysiem l.aly-utt design

Selection of equipment Design of the organization

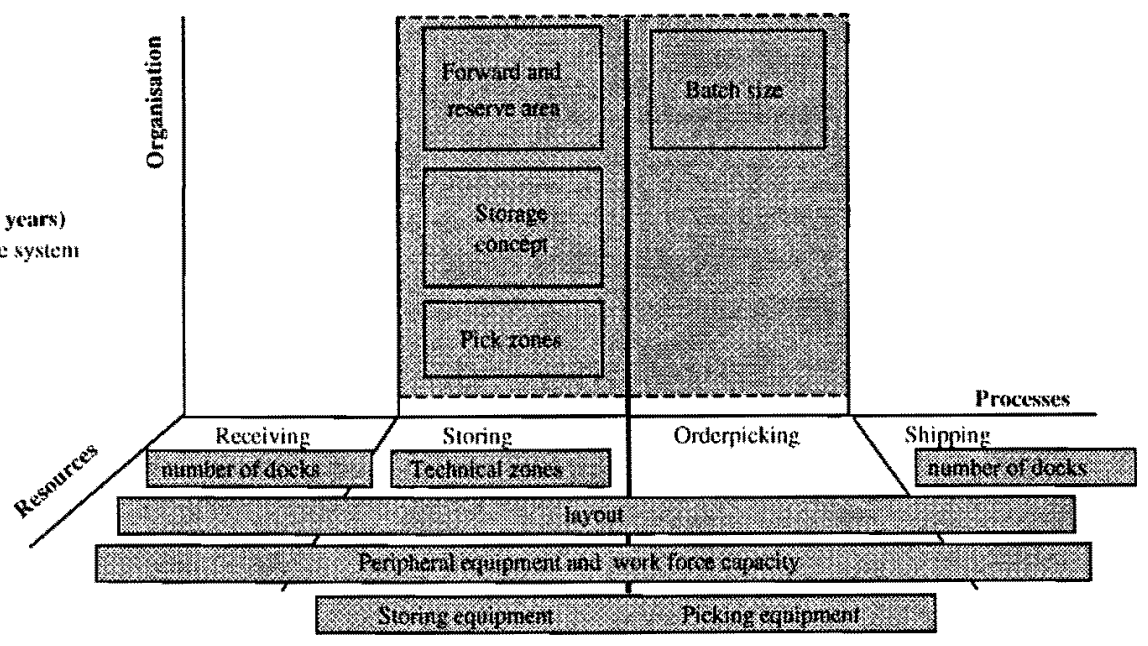

Figure 4.2: The Tactical Level.

- determining the dimensions of the dock area's,

- determining the number of material handling equipment,

- establishing a layout of the overall system,

- determining the number of personnel.

The design problems on the tactical level and their interaction are visualized in figure 4.2 .

The relations between the various problems is less strong than at the strategic level. However, the different storage rules that constitute the storage policy again are strongly interrelated. Also, the storage policies relate to the other organizational policies, since they all influence the maximum throughput of the warehouse, and can not be optimized independently.

All these design problems aim at optimizing performance criteria, such as the throughput, the response times and the storage capacities while minimizing additional investment and operational costs. Minimizing operational costs in particular often boils down to minimizing the required work force.. Obviously, the outcomes of the decisions made here have a strong impact on the remaining problems to be solved at the operational level. 


\subsection{Operational Level}

At the operational level, processes have to be carried out within the constraints set by the strategic and tactical decisions made at the higher levels. Since interfaces between different processes are typically handled within the design problems at the strategic and tactical level, this implies that at the operational level policies have less interaction and therefore can be analyzed independently. The main decisions at this level concern assignment and control problems of people and equipment. Decisions concerning the storage process at the operational level are:

- the assignment of replenishment tasks to personnel,

- the allocation of incoming products to free storage locations, according to the storage concept determined at the tactical level.

Concerning the orderpicking process, decisions are related to:

- batch formation or order sequencing, in line with the batch sizes determined at the tactical level,

- the assignment of picking task to orderpickers,

- the sequencing of picks per order (routing),

- the selection of a dwell point for idle orderpick equipment,

- the assignment of products to sorter chutes (or lanes).

Finally, the assignment of arriving and departing trucks to docks is also a control decision.

The design problems on the operational level are visualized in figure 4.3.

In closing this section we again emphasize the strong hierarchical relationships between decisions made at the strategic, tactical and operational level. In addition, various problems at the strategic level appear to be highly interrelated as well. To a lesser extent this holds also for the tactical level, whereas decisions made at the operational level often can be considered independently. 


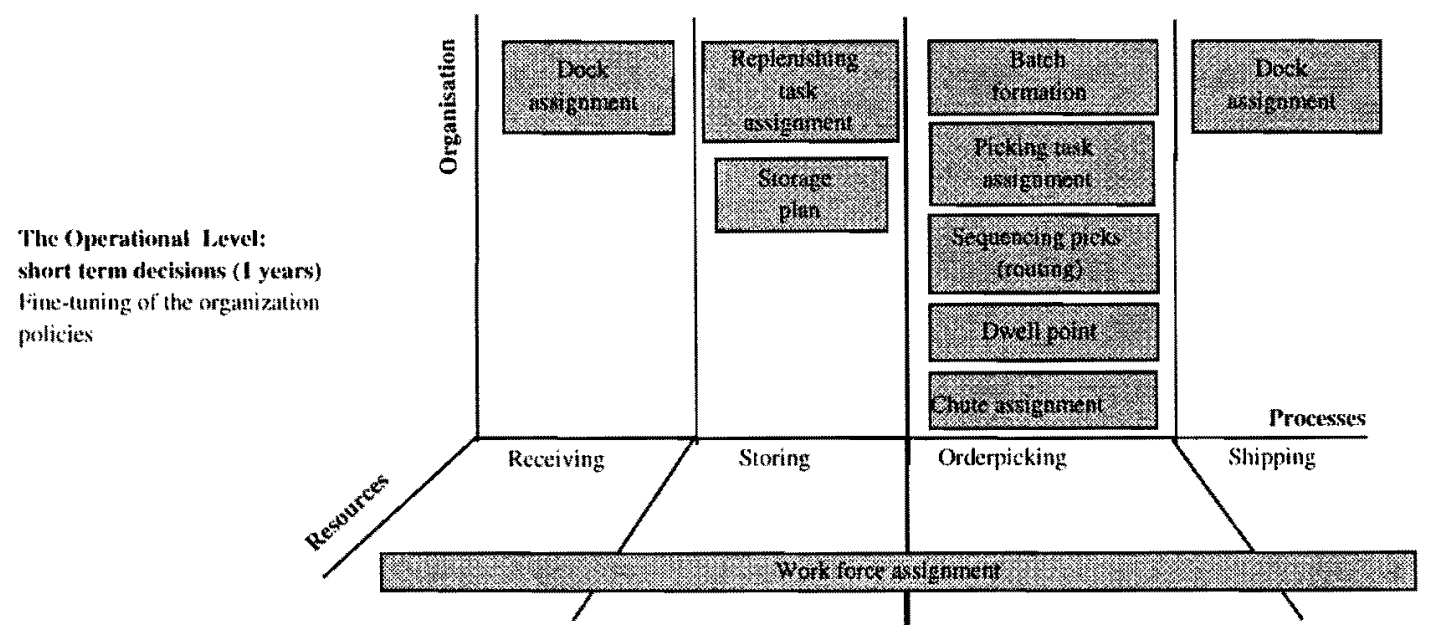

Figure 4.3: The Operational Level.

\section{A Review of Warehousing Models}

In this section we present an overview of models and algorithms proposed in the literature for warehouse design, planning and control. In doing so, we follow the classification of problems at a strategic, tactical or operational level. At each level, we further discuss papers within specific problem domains but in addition classify them along the lines outlined at each of the three levels in Section 4 (see also figure 5.1). Apart from the design problems, we briefly discuss some previous literature overviews and some papers on warehouse design methods.

\subsection{Warehouse Literature Overviews}

In 1971, 1982 and 1983 respectively, Miebach [86], Matson and White [83] and McGinnis et al. [46] reviewed the operations research and material handling literature. They concluded that important gaps in the research fields existed and that most research seemed to concentrate on rather limited problems. In 1992, Goedschalckx created a WWW-page ${ }^{1}$ with an cxtensive list of publications. In 1996, Van den Berg [10] surveyed the literature on planning and organization of warchousing systcms.

\footnotetext{
${ }^{1}$ htt.tp://www.isye.gatech.edu/peoplc/faculty/Marc_Goetschalckx/research.html
} 


\subsection{Warehouse Design Methods}

Apart from specific warehouse design problems, a number of publications deal with the structure of the design method as such.

Ashaycri and Geldcrs [3] revicw the litcrature concerning warchouse design and concluded that a purc analytical approach, as well as an approach that solcly uses simulation, will in general not lead to a practical general design method. However, they suggest that a combination of the two approaches may lead to a good design method. Ashayeri and Goctschalckx [4] provide a stcp-wise gencral design procedurc. Duve and Böcker [28] propose a step-wise design method for warchouse design and provide several cxamples. Yoon and Sharp [125], [126] and [127] suggest an claborate conceptual proccdure for the design of an orderpick systcm. Duve and Mantel [29] discuss Logitrace, a decision support system based on a step-wise design procedure. Frazelle and Hackman [42] provide an empirical study concerning the evaluation of warchouses by means of benchmarking. Brynzér et al. [22] propose an cvaluation method based on the Zero-Based-Analysis methorl. Rupp [109] suggests an hicrarchical design method. Gray et al. [52] also propose a hicrarchical design method and describe the application of their method by an cxample design. Rink and Waibel [99] describe Lasys, a German decision support system for warchouse design.

\subsection{Warehouse Design Problems: Strategic Level}

At the stratcgic level, two problem clusters have been identified: one dealing with the selection of systems and equipment based on technical capabilities, and the second one dealing with the design of the process flow and the selection of warchouse systems based on economic considerations. With respect to the first cluster, we found no publications that specifically concern this problem. A limited number of publications dcals with problems in the second clustcr. Roll et al. [101] propose a systematic procedure for determining the size of a warchouse container. Oser [88] provides an analysis of an automated transfer car storage and retricval system by comparing this system to some alternatives, based on approximations of system performance. Kescrla and Peters [68] compare the performance of a standard AS/RS with a dual-shuttle AS/RS, using analytical expressions and simulation. Dunkin [27] devclops a design algorithm for warehouses containing tote-sized loads. A very interesting study has been published by Sharp et al. [117], who compare, on a cost basis, several competing storage and retrieval equipment types for itcm picking. Both strategic design problems are discussed by Schmidt [111]. 
He cvaluates an automated satellite storage system, by analyzing the hardware attributes, as well as the organization and the resulting warehouse performance.

In conclusion, the number of publications concerning design problems on a strategic level appears to be limited, despite the fact that at this level the most far-reaching decisions are made. Most publications analyze the performance of a warchouse in order to be able to compare the system with alternative ones. Only one publication explicitly analyzes multiple competing warehouse systems.

\subsection{Warehouse Design Problems: Tactical Level}

At the tactical level, most decisions concern the determination of resource dimensions and the design of the organization. The publications in this subsection are classificd according to storage system type. A classification following the topics of Subsection 4.2 is presented in figure 5.1.

Determining the sizc and layout of conventional warchouses has becn the topic of several publications. Berry [13] and Bassan et al. [8] analyze the layout of a conventional warchouse. They provide an optimization model to determine the optimal dimensions of the layout, in order to minimize handling distance, landling time, space utilization or costs. Rosenblatt and Roll [103] present a design procerlure comprising both simulation and analytical methods in order to detcrmine the size and layout of a conventional warchouse, concentrating on the storage capacity. Also, they present an analysis of the required storage capacity as a function of product and order characteristics (sce [104]). Pandit and Palckar [93] study the effect of the layout of a conventional warehouse on the response time, using analytical models and simulation.

De Kostcr [69] proposes a modeling and analysis method for pick-to-belt orderpick systcms that uses analytical expressions to approximate the maximum throughput.

Marnix and Sharp [81] and Sharp et al. [115] evaluate the performance of several configurations of a carouscl system. Rouwcnhorst ct al. [108] determine the maximum throughput and the response time of a carousel system, using stochastic models. Spee [118] analyzes a carouscl system in combination with an orderpick robot and derives analytical expressions for the maximum throughput.

Bozer et al. [20] consider end-of-aisle orderpicking systems. They model the performance of a storage system that consists of multiple miniload systems by deriving analytical expressions, and develop a design algorithm to determine the optimal configuration. In [21], they generalize their algorithm to other configura- 
tions of the orderpick system. Foley and Frazelle [39] derive closed-form analytical expressions for the maximum throughput of a miniload system.

Karasawa [66] and Ashayeri et al. [2] analyze the AS/RS by deriving formulas that approximate the performance of the system as a function of several design characteristics and provide an optimization model to design an cconomical AS/RS. Bozcr and Whitc [19] present analytical expressions for the travel time in an AS/RS. These results have been extended by Chang et al. [24] who incorporate accelcration and decelcration effects. Pan and Wang [92] provide analytical cxpressions for the maximum throughput of an AS/RS with dual commands and a class-based storage policy and evaluate the approximation of the discrete storage rack by a continuous rack. Meller and Mungwattana [84] develop analytical expressions for the maximum throughput of a multi-shuttle AS/RS. Roscnblatt et al. [105] suggest a procedure, including both simulation and analytical methods, to detcrmine the size of an AS/RS systcm, considering constraints on the maximum throughput and the response time. Randhawa and Schroff [97] extend this studly by including an analysis of the storage capacity and the influence of the location of the I/O-point, using simulation. Hwang and Ko [60] propose a procedure to detcrmine the size of multi-aisles AS/RS's, based on analytical expressions, by varying the number of crancs and the storage policy. Meller and Mungwattana [85] analyze the maximum throughput of a multi-shuttle AS/RS by means of stochastic models and simulation. Linn and Wysk [74] determine the dwell point, the storage policy and the retrieval sequences of an AS/RS with the aid of simulation, and propose a decision trce. In addition, the authors propose an expert system on the opcrational control of an AS/RS [75]. Van den Berg and Gademann [12] analyze multiple organization policies of the AS/RS on the influence on storage capacity, the maximum throughput and the response time. Forward/reserve division has becn analyzed, together with routing, ABC-classification and sequencing of the storage requests, with the aid of simulation.

Stadtler [120] analyzes the impact of the size of a Chaotic Direct Sorted (CDS) warchouse, proposing a procedure consisting of simulation and cnumcration.

Apart from storage systems, some publications concern other systems or arc more general. By means of a simulation study, Bozer and Sharp [18] and Bozer ct al. [15] and [16] analyze the performance of a sorting system under variation of the number of output lanes, order characteristics, and control policies. Larson et al. [71] devclop a procedure for class-based storage, related to both the systcm dimensions and the layout. Sharp et al. [116] perform a simulation study to analyze the configuration of input/output conveyors of an AS/RS, and focus both 
on layout and control. Gromann [53] analyzes the selection of equipment for the loading of a truck with packages, providing a qualitative comparison. Sharp et al. [114] detcrmine the selection of orderpick equipment; they compare pick-tolight systcms to alternative systems through both a quantitative and a qualitative comparison within some case studics. Bunde and Graves [23] provide analytical cxpressions of the maximum throughput of a palletizer systcm as a function of its dimension. Pliskin and Dori [96] propose an evaluation procedure for warchousc layouts by a multi-criteria analysis bascd on user proferences.

In conclusion, many papers at the tactical level concern the performance of, mostly automated, warchousing systcms.

\subsection{Warehouse Design Problems: Operational Level}

At the operational level, most decisions concern the assignment of tasks to, and the scheduling and control of people and equipment. The publications in this subsection are grouped according to list of topics discussed in Subsection 4.3.

\subsubsection{Batching}

Elsaycd and Stern [35] test 24 batching algorithms with the aid of simulation. Elsayed and Unal [36] derive analytical cxpressions to evaluate batching algorithms. Rosenwein [107] analyzes the maximum throughput in a conventional warchouse with batching by mcans of a simulation study. Gibson and Sharp [44] analyzc order batching procedures for sort-whilc-pick orderpick opcration, and in [45] they study two now batching procedures, again by simulation. Armstrong ct al. [1] cvaluate batching algorithms for a pick-to-belt warchouse with a sorter system. Pan and Liu [91] analyze batching for a person-on-board AS/RS using simulation in an attempt to maximize the throughput. Elsayed [33] proposes an algorithm for batch formation in a multi-aisles AS/RS system with a sorting system. Hwang ct al. [59] and Hwang and Lee [61] analyze batching algorithms for an AS/RS with the aid of simulation.

\subsubsection{Storage policies}

Goctschalckx and Ratliff [50] evaluate storage policies for block storage through an analytical study. Marsh [82] has been working on the same problem but evaluates two alternative policies. Jarvis and McDowell [64] propose a heuristic for the storage policy in a conventional warehouse. Roll and Rosenblatt [100] analyze the 
storage capacity of conventional warchouses with alternative storage policies, using simulation. Van den Berg and Sharp [122] propose a procedure based on linear programming for product allocation in a warehouse consisting of a forward and a reserve arca, to minimize the costs of orderpicking and replenishment. Bartholdi and Platzman [7] provide a storage policy for a carousel, based on the numbering of bins. Van Oudheusden and Zwu [90] propose a storage algorithm for a personon-board AS/RS with recurrent orders, and evaluate the algorithm by means of a simulation study. Wilhelm and Shaw [123] present an empirical study concerning the storage policy of an AS/RS. Hausman et al. [58], Yang [124], Rosenblatt and Eynan [102], Goetschalckx and Ratliff [49], Eynan and Roscnblatt [38], Kouvelis and Papanicolaou [70], and Malmborg [78] all analyze class-bascd storage in an AS/RS, assuming single commands. They develop analytical methods to determine the optimal dimensions of the zones, considering storage capacity and maximum throughput. Malmborg [77] cvaluates the storage policy for an AS/RS with zoning constraints, and proposes a simulated annealing algorithm, to maximize the storage capacity. Ashaycri ct al. [5] evaluate the maximum throughput of an AS/RS under differcnt storage policies, by deriving analytical cxpressions. Jaikumar and Solomon [63] analyze the relocation of items in an AS/RS and develop an algorithm. Muralidharan et al. [87] evaluate threc heuristics for the same problem through a simulation study. Guenov and Reaside [55] and Lec [72] analyzc class-bascd storage for a multi-command AS/RS through simulation. Kaylan and Medciros [67] cvaluate storage policies for a miniload system with multiple I/O points. Stadtler [119] suggests storage algorithms for the Decp Lane Storage System that minimize the number of relocations. Frazclle and Sharp [40] and Roscnwein [106] analyze corrclated storage policies and develop a general solution approach. Beavers [9] presents a paper on the same topic and discusses a computerized implementation. Malmborg and Bhaskaran [79] evaluate the Cubc per Order Index storage policy for different kinds of warchouses, based on analytical cxpressions for the maximum throughput. Park and Webster [94] derive analytical cxpressions for the maximum throughput of multiple threc-dimensional storage systems with the cubic-in-time storage policy.

\subsubsection{Routing and sequencing}

Gelders and Hecremans [43] analyze routing in a conventional warehouse. Goctschalckx and Ratliff [47] and [48], Hall [56] and De Koster and Van der Poort [26] determine analytical expressions to evaluate the routing in a conventional ware- 
housc. Ratliff and Rosenthal [98] present an algorithm for the routing in a conventional warchouse, based on dynamic programming, which focuses on the maximum throughput. Gucnov and Rcaside [54] analyze three heuristics for two-dimensional itcm picking in a conventional warchousc. Bozer et al. [17] suggest an algorithm for routing in a two-dimensional rack with more than two locations to be visited, and test its performance with the aid of a simulation study. Kanet and GonzaloRamirc [65] cvaluate sequencing policies in an AS/RS. In addition to the usual costs associatod with retricval, this study considers also the cost of a location breakdown. Cormicr [25] presents an algorithm for sequencing retricvals with duc-datcs in a AS/RS, using dynamic programming. Linn and Xic [76] suggest an sequencing rule for the same problem. Elsayed ct al. [34] and Lce and Kim [73] extend this problem with penalties for carly retrieval and suggest a sequencing procedure. Han et al. [57] analyze the noarest-neighbor and the shortest-leg retrieval policies for an $\mathrm{AS} / \mathrm{RS}$, based on analytical expressions and simulation. Eynan and Rosenblatt [37] cvaluate the nearest-neighbor retrieval policy for an AS/RS with class-based storage. Eben-Chaime [30] analyze the difference between block scheduling and dynamic sequencing in an AS/RS. Seidmann [113] proposes an adapted scquencing rule that incorporates scasonal demand fluctuations of the products.

\subsubsection{Dwell point selection}

Egbelu [31] presents an algorithm for the dwell point selection, using lincar programming. Also, Egbclu and Wu [32] evaluate scveral dwell point policies with the aid of simulation. Hwang and Lim [62] improve these algorithms. Peters et al. [95] present an analysis to approximate the response time for multiple AS/RS configurations and dwell point policies.

\subsubsection{Storing and sequencing}

Graves et al. [51] evaluate the impact of sequencing and class-based storage policies on warchouse performance, based on analytical expressions for continuous racks and numcrical procedures for discrete systems. Van Oudheusden et al. [89] analyze this problem for a person-on-board AS/RS, by means of a case study using simulation. Stadtlor [119] proposes a concept for the opcrational control of an CDS-warchouse, which incorporates tabu search. Schwartz et al. [112] use simulation to approximate the maximum throughput of an AS/RS as a function of storage and sequencing policies. 


\subsubsection{Miscellaneous}

Sarker and Babu [110] rovicw the literature concerning the operational control of AS/RS's. Van den Berg [11] analyzes a number of operational control problems: forward rescrve allocation, class based storage, routing in carousels and AS/RS's, and dwell point selection. Askin and Standridge [6] make some general remarks on organizational issues for conventional and autornated warehouses.

\subsection{Overview}

Figure 5.1 presents a clustering of the literature discussed above, following the list of topics discussed in Section 4. Publications that cover morc than one category are accounted more than once.

From Figure 5.1 we obscrve that most of the rescarch scems to concentrate on finc-tuning the warchouse organization, i.e. on the tactical and in particular on the opcrational level. About 70 publications analyze isolated optimization problcms concerning warehouse organization, which sharply contrasts with the 6 publications concerning strategic design problcms. Since most costs of a warchouse are detcrmined at an carly stage, more rescarch on strategic issucs is badly needed.

Also, the review indicates that most of the research concerning the tactical and the opcrational design level analyzes automated storage systems. In particular the AS/RS is a popular rescarch theme; only a fow publications discuss conventional warchouses or warchouse cquipment. More research on conventional systems should be cncouraged. Furthermore, no publications were found on tactical design problems like the dimensioning of the dock area and the determination of the number of personnel, although these problems are far from trivial and often represent substantial costs.

In addition, most papers scem to focus on isolated warchouse organizational policies. Optimizing such a policy may at best lead to a local optimization. As an cxample, consider an optimal batch size policy that neglects the possible effects of ABC-zoning. We strongly advocate research aiming at an integration of problems that have to be clustered at one level (compare the discussion in Section 4).

In conclusion, the overall picture that cmerges secms to suggest that current, rescarch, although uscful in itself, is still too much scattered, almost completely analytical of naturc, and much less oriented towards a synthesis of modcls and methods. In particular more research is necded on strategic design problems and on the integration of various models and methods in order to develop a systcmatic 


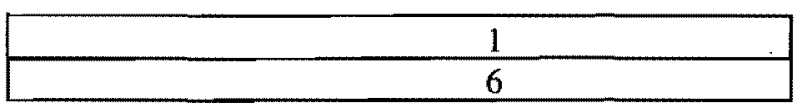

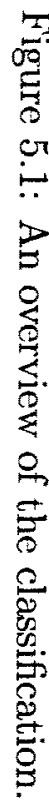
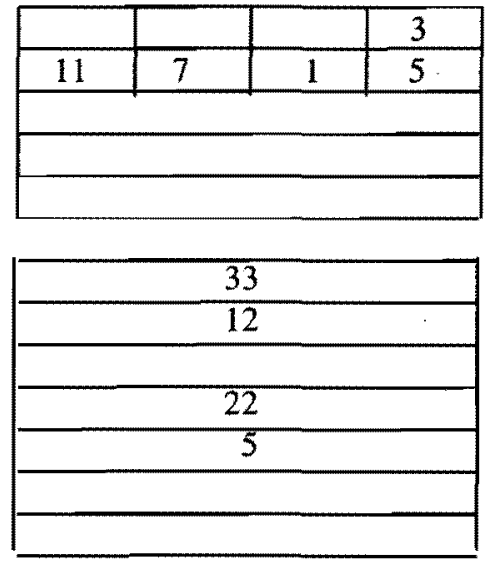

产 总 总

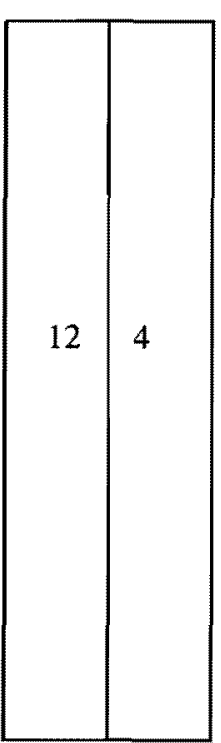

strategic level (system type selection) technical feasibility

design objectives

\section{tactical level (dimensioning)}

design the organisation

dimension the system(s)

dimension the dock area's

dimension the number of equipment

dimension the number of personnel

\section{operational level (fine-tuning)}

assignment of replenishing tasks to personnel

allocation of incoming goods

batch formation or order sequencing

assignment of picking task to orderpickers

sequencing of picks per order (routing)

dwell-point selection

dock assignment

sorter chute (or lane) assignment

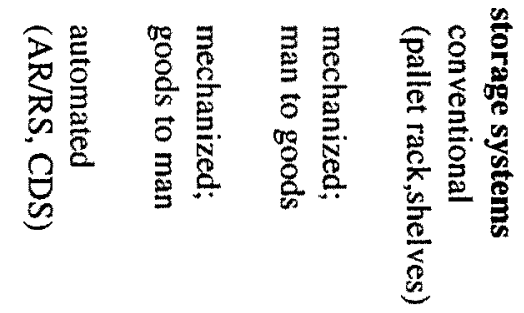


design methodology.

\section{Design Oriented Research}

In the preceding section, the literature review showed that most of the current research is primarily devoted to the analysis of relatively clean, isolated systems, instcad of to a synthesis of models into an overall design model. Basically, a similar remark holds for the majority of studies devoted to operations management problems. The lack of design oriented papers is in sharp contrast with the need for integrated models and techniques. In this section we elaborate on the differences between analysis oriented and design oriented research and offer some guidelines to support a greater emphasis on the latter.

Typically, analysis oriented research is concerned with limited, woll-defined problems. These problems often satisfy the following properties (sec also De Boer [14]):

- the porformance function (or goal function) can be expressed analytically or can be quantificd,

- the set of available alternatives is fully known,

- the probability of uncertain cvents is known and the effects can be quantificd,

- the interaction with the environment is neglected or casily modelled.

Although analysis oriented rescarch may comprise highly complex models and methods, it is generally easy to value and to communicate. The revicw presented in Section 5 reveals that the rescarch on warchousing systems primarily falls within this catcgory. An example is provided by the optimization of routes in an automated storage and retricval system (AS/RS). This problem concerns the sequencing of storage and retricval operations in an AS/RS, in order to decrease the expected route length and thereby to increase the throughput. This problem has all properties mentioned above. Indeed, no less than 42 publications concern route length optimization for an AS/RS.

In contrast, problems cncountered on a strategic level during warehouse design often are less well-defined:

- The performance function that cvaluates a solution is often complex; it consists of multiple objectives, and is partly qualitative. For instance, flexibility is hard to quantify. 
- The set of alternatives is large, since many alternatives of warehouse hardware systems and organization policies exist and can be combined in multiple ways; c.g., a warchousc may have three or more types of warehouse storage systems and may usc multiple organization policies. Enumeration of all feasible designs in order to find the optimal solution is often practically impossible.

- Stochastic behavior such as the failure of warehouse equipment and human faults during orderpicking are difficult to quantify.

- The judgement of a complete design can at best be partial, since future warchousc capacity demand, as well as the future product types to be stored, are hard to predict.

- The design of subsystems or policies can not be isolated, duc to the interaction with other subsystems and policies. In Section 4 we found that warchouse design problems at a strategic or tactical level can not casily be decomposed into multiple isolated subproblems.

Although we do not offer a complete road map, we strongly advocate a more design oricnted rescarch approach for warchousing problems. Below, we offer some guidelines that may help in pursuing such rescarch.

- The use of a reference model to place design problems in a general perspective. The charactcrization along the three axes processes, resources and organization of Section 2, and the classification of problems in Sections 3 and 4 may provide the basis for such a reference model.

- An inventory of warchouse systems, equipment and techniques is indispensable as a basis for comparing alternatives (sce also Tompkins et al. [121]). In particular, the suitability of systems for particular product market combinations (slow movers or fast movers, item picking or case picking) should be investigated.

- At the strategic level, the development of more cost oriented models is nceded. Also, the translation from a functional to a technical spccification, based upon knowledge of existing systems, descrves more attention.

- Studies that aim at an integration of various subsystems and that concentrate on interfacing problems should be encouraged. 
In summary, we emphasize the need for rescarch oriented towards a synthesis of currently isolated models and techniques, as a basis for decision support in designing complete warehousing systems. Such rescarch is felt to fill an important gap between the scicntific literature and the practice of warchouse design and management.

\section{Conclusions}

In this paper, we have presented a characterization of warchouses along the vicws processes, resources and organization. In addition, wo have presented a classification of warchouse design and control problems along these three axes at a stratcgic, tactical and operational level, respectively. In addition, we presented an extensive review of the literature and concluded that the majority of papers is primarily analysis oriented and does not pursue a synthesis of modcls and techniques as a basis for warchouse design. Some guidelines towards a more design oricnted approach have becn offered.

Future work will concentrate on the development of a complete reference model and a systematic design approach for warchousing systems. In particular tradeoffs between costs and operational performance of integrated systems will be the subject of future studies.

\section{References}

[1] R.D. Armstrong, W.D. Cook, and A.L. Saipe. Optimal batching in a semiautomated order picking system. Journal of the Operational Research Society, 30(8):711-720, 1979.

[2] J. Ashaycri, L. Gelders, and L. van Wassenhove. A microcomputer-based optimisation model for the design of automated warchouses. International Journal of Production Research, 23(4):825-839, 1985.

[3] J. Ashayeri and L.F. Gelders. Warchouse design optimization. European Journal of Operational Research, 21:285-294, 1985.

[4] J. Ashaycri and M. Goctschalckx. Analysis and design of order picking systems. In 9th International Conference on Automation in Warehousing, pages $125-135,1988$. 
[5] J. Ashaycri, R. Heutz, and H.C. Veraart. A new approach for the determination of expected traveling time in an AS/RS under any assignment policy. In Progress in material handling research: 1996, pages 51-69, The Matcrial Handling Industry of Amorica, Charlotte, NC, 1996.

[6] R.G. Askin and C.R. Standridge. Modeling and analysis of manufacturing systems. John Wilcy \& Sons, Ncw York, 1993. Chapter 10.

[7] J.J. Bartholdi, III and L.K. Platzman. Design of efficient bin-numbering schemes for automated warehousc carousel storage systems. Technical Report MHRC-TR-85-09, Georgia Institute of Technology, 1985.

[8] Y. Bassan, Y. Roll, and M.J. Rosenblatt. Internal layout design of a warchousc. AIIE Transactions, 12(4):317-322, 1980.

[9] M.K. Beavers. An an automated system for dynamic reconfiguration of forward picking arcas. Tcchnical Report MHRC-TD-93-19, Gcorgia Institute of Tochnology, 1993.

[10] J.P. van den Berg. Aliterature survey on planning and control ofwarchousing systems. Working Paper, LPOM-96-12, University of Twente, Fac. of Mech. Eng., Enschede, The Netherlands, 1996.

[11] J.P. van den Berg. Planning and control of warehousing systems. PhD thesis, University of Twente, Fac. of Mech. Eng., Enschede, The Netherlands, 1996.

[12] J.P. van den Berg and A.J.R.M. Gademann. Simulation study of an autonated storage/retricval system. Working Paper, LPOM-97-11, University of Twente, Fac. of Mech. Eng., Enschede, The Netherlands, 1997.

[13] J.R. Berry. Elements of warchouse layout. International Journal of Production Rescarch, 7(2):105-121, 1968.

[14] S..J. de Bocr. Decision methods and techniques in methodical engineering design. PhD thesis, University of Twente, Fac. of Mech. Eng., Enschede, The Nethorlands, 1989.

[15] Y.A. Bozer, M.A. Quiroz, and G.P. Sharp. An evaluation of alternative control strategies and design issues for automated order accumulation and sortation systems. Material Flow, 4:265-282, 1988. 
[16] Y.A. Bozer, M.A. Quiroz, and G.P. Sharp. Throughput analysis of order accumulation and sortation systems: Part ii. Technical Report MHRC-TR87-03, Georgia Institute of Technology, 1991.

[17] Y.A. Bozer, E.C. Schorn, and G.P. Sharp. Geometric approaches to solve the Chebyshev traveling salesman problem. IIE Transactions, 22(3):238254, 1990.

[18] Y.A. Bozer and G.P. Sharp. An empirical evaluation of a general purposc automated order accumulation and sortation system used in batch picking. Material Flow, 2(2):111-131, 1985.

[19] Y.A. Bozer and J.A. White. Travel-time models for automated storage/rotrieval systems. IIE Transactions, 16(4):329-338, 1984.

[20] Y.A. Bozer and J.A. White. Design and performance models for end-of-aisle order picking systems. Management Science, 36(7):852-866, 1990.

[21] Y.A. Bozcr and J.A. White. A gencralized design and performance analysis for end-of-aisle ordor picking systems. IIE Transactions, 28(4):271-280, 1996.

[22] H. Brynzer, M. Johansson, and L. Medbo. A methodology for evaluation of order picking systems as a base for system design and managerial decisions. International Journal of Operations 8 Production Management, 14(3):126$139,1994$.

[23] L.M. Bunde and R..J. Graves. The multi-line palletizer material flow problcm. In Progress in material handling research: 1996, pages 179-191, The Matcrial Handling Industry of Amcrica, Charlotte, NC, 1996.

[24] D.-T. Chang, U.-P. Wen, and J.T. Lin. The impact of acceleration/deceleration on travel-time models for automated storagc/retrieval systcms. IIE Transactions, 27(1):108-111, 1995.

[25] G. Cormier. On the scheduling of order-picking operations in single-aisle automated storage and retricval systems. In A. Kusiak, cditor, Modern production management systems, pages 75-87. Elscvicr Scicnce Publishers B.V. (North-Holland), 1987. 
[26] R. de Koster and E. van der Poort. Routing orderpickers in a warchouse: A comparison between optimal and heuristic solutions. Technical report, Erasmus University Rotterdam, 1996.

[27] A.E. Dunkin. Analysis and design of storage and retricval systems for tote size loads. Technical Report MHRC-TD-88-01, Georgia Institute of Technology, 1989.

[28] B. Duve and T. Böcker. Automatische kommissionicrsyteme - planung, gestaltung und realisierung. Hebezeuge und Fördermittel, 33(1,2):30-34, 1993. In German.

[29] B. Duve and R. Mantel. Logitrace: a decision support system for warchousc design. In Progress in material handling research: 1996, pages 111-124, The Material Handling Industry of America, Charlotte, NC, 1996.

[30] M. Eben-Chaime. Opcrations scquencing in automated warchousing systems. International Journal of Production Research, 30(10):2401-2409, 1992.

[31] P.J. Egbolu. Framework for dynamic positioning of storage/retrieval machincs in an automated storage/retrieval system. International Journal of Production Research, 29(1):17-37, 1991.

[32] P.J. Egbelu and C.-T. Wu. A comparison of dwcll point rules in an automated storage/retricval system. International Journal of Production Research, 31(11):2515-2530, 1993.

[33] E.A. Elsaycd. Algorithms for optimal matcrial handling in automatic warchousing systems. International Journal of Production Research, 19(5):525535,1981 .

[34] E.A. Elsayed, M.-K. Lee, S. Kim, and E. Scherer. Sequencing and batching. procedures for minimizing carliness and tardiness penalty of order retrievals. International Journal of Production Research, 31(3):727-738, 1993.

[35] E.A. Elsayed and R.G. Stern. Computerizcd algorithms for order processing in automated warchousing systcms. International Journal of Production Research, 21(4):579-586, 1983. 
[36] E.A. Elsayed and O.I. Unal. Order batching algorithms and travel-time estimation for automated storage/retricval systems. International Journal of Production Research, 27(7):1097-1114, 1989.

[37] A. Eynan and M..J. Rosenblatt. An interleaving policy in automatod storagc/retrieval systems. International Journal of Production Research, 31(1):1-18, 1993.

[38] A. Eynan and M.J. Rosenblatt. Establishing zones in single-command classbased rectangular AS/RS. IIE Transactions, 26(1):38-46, 1994.

[39] R.D. Folcy and E.H. Frazelle. Analytical results for miniload throughput and the distribution of dual command travel time. IIE Transactions, 23(3):273$281,1991$.

[40] E.A. Frazclle and G.P. Sharp. Correlated assignment strategy can improve ordor-picking opcration. Industrial Engineering, 4:33-37, 1989.

[41] E.H. Frazellc. Material Handling Systcms and Terminology. Lionheart Pullishing Inc., Atlanta, GA, 1992.

[42] E.H. Frazelle and S.T. Hackman. The warchouse performance index: A single-point metric for benchmarking warchouse performance. Technical Report MHRC-TR-93-14, Georgia Institute of Technology, 1994.

[43] L. Gelders and D. Hecremans. Het traveling salesman problecm toegepast op order picking. Tijdschrift voor Economie en Management, 39(4):381-388, 1994. In Dutch.

[44] D.R. Gibson and G.P. Sharp. Order batching procedures. Technical Report MHRC-TR-90-05, Georgia Institute of Technology, 1991.

[45] D.R. Gibson and G.P. Sharp. Order batching procedures. European Journal of Operational Research, 58(1):57-67, 1992.

[46] L. Mc Ginnis, J. Trevino, and J.A. White. A bibliography on material handling systems analysis. Technical Report MHRC-TR-83-06, Gcorgia Institute of Technology, 1983.

[47] M. Goctschalckx and H.D. Ratliff. An efficient algorithm to cluster order picking items in a wide aislc. Engineering Costs and Production Economics, 13(1):263-271, 1988 . 
[48] M. Goetschalckx and H.D. Ratliff. Order picking in an aislc. IIE Transactions, 20(1):53-62, 1988.

[49] M. Goctschalckx and H.D. Ratliff. Shared storage policics based on the duration stay of unit loads. Management Science, 36(9):1120-1132, 1990.

[50] M. Goetschalckx and H.D. Ratliff. Optimal lane depths for single and multiple products in block stacking storage systems. IIE Transactions, 23(3):245$258,1991$.

[51] S.C. Graves, W.H. Hausman, and L.B. Schwarz. Storage-retrieval intcrleaving in automatic warchousing systems. Management Science, 23(9):935-945, 1977.

[52] A.E. Gray, U.S. Karmarkar, and A. Scidmann. Design and operation of an ordcr-consolidation warchousc: models and application. European Journal of Operational Research, 58(1):14-36, 1992.

[53] G. Grossman. Development of a mobile handling robot for packages. In Progress in material handling research: 1996, pages 193-205, The Material Handling Industry of America, Charlotte, NC, 1996.

[54] M. Guenov and R. Racside. Real time optimization of man on board orderpicking. In 10th International Conference on Automation in Warehousing, pages 89-94, 1989.

[55] M. Gucnov and R. Racside. Zone shapes in class bascd storage and multicommand order picking when storage/retricval machines are used. European Journal of Operational Rescarch, 58(1):37-47, 1992.

[56] R.W. Hall. Distance approximations for routing manual pickers in a warchousc. IIE Transactions, 25(4):76-87, 1993.

[57] M.-H. Han, L.F. McGinnis, J.S. Shieh, and J.A. White. On sequencing retricvals in an automated storage/retrieval system. IIE Transactions, 19(1):56-66, 1987.

[58] W.H. Hausman, L.B. Schwarz, and S.C. Graves. Optimal storage assignment in automatic warchousing systems. Management Science, 22(6):629-638, 1976. 
[59] H. Hwang, W. Back, and M.-K. Lec. Clustering algorithms for order picking in an automated storage and retrieval system. International Journal of Production Research, 26(2):189-201, 1988.

[60] H. Hwang and C.S. Ko. A study on multi-aisle system served by a single storage/retrieval machine. International Journal of Production Research, 26(11):1727-1737, 1988.

[61] H. Hwang and M.-K. Lee. Order batching algorithms for a man-on-board automated storagc and retrieval system. Engineering Costs and Production Economics, 13:285-294, 1988.

[62] H. Hwang and J.M. Lim. Deriving an optimal dwell point of the storagc/retricval machine in an automated storagc/retrieval system. International Journal of Production Research, 31(11):2591-2602, 1993.

[63] R. .Jaikumar and M.M. Solomon. Dynamic operational policies in an automated warchousc. IIE Transactions, 22(4):370-376, 1990.

[64] J.M. Jarvis and E.D. McDowcll. Optimal product layout in an order picking warchousc. IIE Transactions, 23(1):93-102, 1991.

[65] J.J. Kanct and R. Gonzalo Ramircz. Optimal stock picking decisions in automated storago retricval systems. Omega, 14(3):239-244, 1986.

[66] Y. Karasawa, H. Nakayama, and S. Dohi. Trade-off analysis for optimal design of automated warchouscs. International Journal of Systems Science, $11(5): 567-576,1980$.

[67] A. Kaylan and D.J. Modeiros. Analysis of storage policics for miniload AS/AR. Engineering cost and Production. Economics, 13:311-318, 1988.

[68] A. Kescrla and B.A. Peters. Analysis of dual-shuttle automated storage/retricval systcms. Journal of Manufacturing Systems, 13(6):424-434, 1994.

[69] R. de Koster. On the design of a high capacity pick-and-pass orderpicking system. In Progress in material handling research: 1996, pages 253-269, The Material Handling Industry of America, Charlotte, NC, 1996. 
[70] P. Kouvelis and V. Papanicolaou. Expected travel time and optimal boundary formulas for a two-class-based automated storage/retrieval system. International Journal of Production Research, 33(10):2889-2905, 1995.

[71] T.N. Larson, H. March, and A. Kusiak. A heuristic approach to warehousc layout with class-based storage. IIE Transactions, 29(4):337-348, 1997.

[72] M.-K. Lce. A storage assignment policy in a man-on-board automated storage/rctrieval systcm. International Journal of Production Research, 30(10):2281-2292, 1992.

[73] M.-K. Lee and S.-Y. Kim. Scheduling of storage/retricval orders under a just-in-time environment. International Journal of Production Research, 33(12):3331-3348, 1995.

[74] R.J. Linn and R.A. Wysk. An analysis of control strategies for an automated storagc/retricval system. INFOR, 25(1):66-83, 1987.

[75] R.J. Linn and R.A. Wysk. An cxpert system framcwork for automated storage and retrieval system control. Computers 8 Industrial Engineering, 18(1):37-48, 1990 .

[76] R.J. Linn and X. Xic. A simulation analysis of sequencing rules in a pull-based asscmbly facility. International Journal of Production Research, 31(10):2355-2367, 1993.

[77] C.I. Malmborg. Optimization of cubc-per-order index warchouse layouts with zoning constraints. International Journal of Production Research, 33(2):465-482, 1995.

[78] C.I. Malmborg. Storage assignment policy tradeoff. International Journal of Production Research, 34(2):363-378, 1996.

[79] C.J. Malmborg and K. Bharkaran. A revised proof of optimality for the cube-per-order index rule for stored item location. Applied Mathematical Modelling, 14(2):87-95, 1990.

[80] R.J. Mantel and B. Rouwenhorst. A warehouse design model. In Progress in material handling research: 1998, The Material Handling Industry of Amcrica, Charlotte, NC, 1998. 
[81] I. Mardix and G.P. Sharp. Cost and efficiency analysis of the carouscl storage system. Technical Report MHRC-TR-85-08, Georgia Institute of Technology, 1985.

[82] W.H. Marsh. Elements of block storage design. International Journal of Production Research, 17(4):377-394, 1979.

[83] J.O. Matson and J.A. White. Operational research and matcrial handling. European Journal of Operational Research, 11:309-318, 1982.

[84] R.D. Meller and A. Mungwattana. Multi-shuttle automated storage/retrieval systems: analytical models and an application. Technical report, Department of Industrial Engincering, Auburn University, 1995.

[85] R.D. Meller and A. Mungwattana. Multi-shuttle automated storage/retricval systems: analytical models and an application. In Progress in material handling research: 1996, pages 345-373, The Matcrial Handling Industry of Amcrica, Charlottc, NC, 1996.

[86] J. Micbach. Die Grundlagen einer systembezogenen Planung von Stückgutlagern, dargestellt am Beispiel des Kommissionierlagers. PhD thesis, Tcchnische Universität Berlin, Germany, 1971. In German.

[87] B. Muralidharan, R.J. Linn, and R. Pandit. Shuffling heuristics for the storage location assignment in an AS/RS. International Journal of Production Research, 33(6):1661-1672, 1995.

[88] J. Oser. Design and analysis of an automated transfer car storage and retricval systcm. In Progress in material handling research: 1996, pages 457-466, The Matcrial Handling Industry of Amcrica, Charlottc, NC, 1996.

[89] D.L. van Oudheusden, Y.-J.J. Tzen, and H.-T. Ko. Improving storage and order picking in a person-on-board AS/R system. Engineering Costs and Production Economics, 13:273-283, 1988.

[90] D.L. van Oudheusden and W. Zhu. Storage layout of AS/RS racks based on recurrent orders. European Journal of Operational Research, 58(1):48-56, 1992.

[91] C.H. Pan and S.Y. Liu. A comparative study of order batching algorithms. Omega, 23(6):322-328, 1995. 
[92] C.H. Pan and C.H. Wang. A framework for dual command cycle travel time model in automated warehousing systems. International Journal of Production Rescarch, 34(8):2099-2117, 1996.

[93] R. Pandit and U.S. Palekar. Responsc time considerations for optimal warehouse layout design. Journal of Engineering for Industry, 115:322-328, 1993.

[94] Y.H. Park and D.B. Wcbster. Design of class-based storage racks for minimizing travel time in a threc-dimensional storage system. International Journal of Production Research, 27(9):1589-1601, 1989.

[95] B.A. Peters, J.S. Smith, and T.S. Halc. Closed form models for determining the optimal dwell point location in automated storage and retrieval systems. International Journal of Production Research, 34(6):1757-1771, 1996.

[96] J.S. Pliskin and D. Dori. Ranking alternative warchouse arca assignments: a multiattribute approach. IIE Transactions, 14(1):19-26, 1982.

[97] S.U. Randhawa and R. Shroff. Simulation-based design cvaluation of unit load automated storage and retrieval systems. Computers and Industrial Engineering, 28(1):71-79, 1995.

[98] H.D. Ratliff and A.S. Rosenthal. Order-picking in a rectangular warehousc: A solvable casc of the traveling salcsman problem. Operations Research, 31(3):507-521, 1983.

[99] H. Rink and P. Waibel. Scric: Strukturicrte lagerplanung, lasys - cin program zu lagor systcmplanung. Der Betriebsleiter, (11):28-32, 1995. In German.

[100] Y. Roll and M.J. Rosenblatt. Random versus grouped storage policies and their effect on warchouse capacity. Material Flow, 1:199-205, 1983.

[101] Y. Roll, M.J. Rosenblatt, and D. Kadosh. Detcrmining the size of a warchouse containcr. International Journal of Production Research, 27(10):16931704,1989 .

[102] M.J. Rosenblatt and A. Eynan. Deriving the optimal boundaries for class-based automatic storagc/rctrieval systems. Management Science, 35(12):1519-1524, 1989. 
[103] M.J. Rosenblatt and Y. Roll. Warchouse design with storage policy considcration. International Journal of Production Research, 22(5):809-821, 1984.

[104] M.J. Roscnblatt and Y. Roll. Warchouse capacity in a stochastic cnvironment. International Journal of Production Research, 26(12):1847-1851, 1988.

[105] M.J. Rosenblatt, Y. Roll, and V. Zyser. A combined optimization and simulation approach for designing automated storage/retricval systems. IIE Transactions, 25(1):40-50, 1993.

[106] M.B. Rosenwein. An application of cluster analysis to the problem of locating items within a warehouse. IIE Transactions, 26(1):101-103, 1994.

[107] M.B. Rosenwein. A comparison of heuristics for the problem of batching orders for warchousc selection. International Journal of Production Research, 34(3):657-664, 1996.

[108] B. Rouwenhorst, J.P. van den Berg, G.J. van Houtum, and W.H.M. Zijm. Performance analysis of a carousel system. In Progress in material handling research: 1996, pages 495-511, The Material Handling Industry of Amcrica, Charlottc, NC, 1996.

[109] M. Rupp. Vorgehenskonzept für lagerplanungen. Industrie Anzeiger, (15):23-26, 1980. In Gorman.

[110] B.R. Sarker and P.S. Babu. Travel time models in automated storage and retricval systcms: A critical revicw. International Journal of Production Economics, 40:173-184, 1995.

[111] R. Schmidt. Satellitenlagersysteme - Leistungsbestimmung und Betriebsstrategien. TÜV Rhcinland, Köln, Germany, 1991. In German.

[112] L.B. Schwarz, S.C. Graves, and W.H. Hausman. Scheduling policies for automatic warchousing systems: Simulation results. AIIE Transactions, 10(3):260-270, 1978.

[113] A. Scidmann. Intelligent control schemes for automated storage and retricval systcms. International Journal of Production Research, 26(5):931-952, 1988. 
[114] G. Sharp, R. Handelsmann, D. Light, and A. Yeremeyev. Productivity and quality impacts of pick-to-light systcms. In Progress in material handling research: 1996, pages 513-530, The Material Handling Industry of America, Charlotte, NC, 1996.

[115] G.P. Sharp, J. Eckert, and D. Gibson. Order picking using horizontal carouscls. Technical Report MHRC-TR-89-01, Gcorgia Institute of Technology, 1990.

[116] G.P. Sharp, R. Kittell, and K. Hollender. Convcyor input/output systems for pallet AS/RS. Technical Report MHRC-TR-89-02, Georgia Institute of Technology, 1991.

[117] G.P. Sharp, R. Kittell, and K. Hollender. Economics of storage/retrieval systems for item picking. Technical Report MHRC-OP-94-02, Georgia Institute of Technology, 1994.

[118] D. Spee. Automatcl orderpicking system with horizontal racks. In Progress in material handling research: 1996, pages 545-550, The Material Handling Industry of Amcrica, Charlottc, NC, 1996.

[119] H. Stadtlcr. An opcrational planning concept for decp lane storage systcms. Production and Operations Management, 5(3):266-282, 1996.

[120] H. Stadtlcr. Optimal dimensions for automated storage/retrieval systems. In Progress in material handling research: 1996, pages 551-571, The Matcrial Handling Industry of Amcrica, Charlottc, NC, 1996.

[121] J.A. Tompkins, J.A. White, Y.A. Bozcr, E.H. Frazelle, J.M.A. Tanchoco, and J. Trevino. facilities planning. John Wiley \& Sons, New York, 1996.

[122] J.P. van den Berg and G.P. Sharp. Forward-reserve allocation in a unit-load warchouse opcration with picking periods. In Progress in material handling research: 1996, pages 625-638, The Material Handling Industry of Amcrica, Charlotte, NC, 1996.

[123] M.R. Wilhclm and J.L. Shaw. An empirical study of the closest open location rule for AS/RS strorage assignments. In Progress in material handling research: 1996, pages 639-650, The Material Handling Industry of America, Charlotte, NC, 1996. 
[124] M. Yang. Analysis and optimization of class-based dedicated storage systems. PhD thesis, Georgia Institute of Tcchnology, Atlanta, GA, 1988.

[125] C.S. Yoon. A structured procedure for order pick system analysis and design. Technical Report MHRC-TD-91-13, Gcorgia Institute of Technology, 1992.

[126] C.S. Yoon and G.P. Sharp. Example application of the conitive design procedure for an order picking system: Casc study. European Journal of Operational Research, 87:223-246, 1995.

[127] C.S. Yoon and G.P. Sharp. A structured procedure for analysis and design of orderpick systems. IIE Transactions, 28:379-389, 1996. 
Working Papers

WP 1 The Dutch IOR approach to organisational design : an alternative to business process reengineering

WP 2 Simultaneous layout planning, organisation design and technology development : preparing for world class standards in production

Ronald J.H. van de Kuil, Frans M. van Eijnatten, Andre G.W. Peeters and Maarten J. Verkerk

WP 3 A framework for implementation of statistical process control R.J.M.M. Does, A. Trip, W.A.J. Schippers

WP 4 Bounds for performance characteristics : a systematic approach via cost structures G.J. van Houtum, W.H.M. Zijm, I.J.B.F. Adan, J. WesseIs

WP $5 \quad$ Vertekeningen in budgetten : oorzaak, gevolg en probleemaanpak Jeroen Weimer

WP 6 Corporate governance en financiele ondernemingsdoelen : winst, profit en Gewinn Jeroen Weimer en Joost C. Pape

WP 7 A behavioral view on corporate governance and corporate financial goals of Dutch, US, and German firms

Jeroen Weimer and Joost C. Pape

WP 8 Corporate governance : het belang van theorie voor de praktijk

Joost C. Pape en Jeroen Weimer

WP 9 Mixed policies for recovery and disposal of multiple type assembly products : commercial exploitation of compulsory return flows

H.R. Krikke, P.C. Schuur and A. van Harten

WP 10 Balancing stocks and flexible recipe costs and high service level requirements in a batch process industry : a study of a small scale model

W.G.M. Rutten and J.W.M. Bertrand

WP 11 Implementing statistical process control in industry : the role of statistics and statisticians W.A.J. Schippers and R.J.M.M. Does

WP 12 Delivery performance improvement by controlled work-order release and work centerloading

H.P.G. van Ooijen

WP 13 Estimating stock levels in periodic review inventory systems

M.C. van der Heijden

WP 14 Near cost-optimal inventory control policies for divergent networks under fill rate constraints

M.C. van der Heijden

WP 15 Covering a rectangle with six and seven circles

J.B. Melissen and P.C. Schuur

WP 16 Facility layout problemen met vaste oppervlaktes en variabele vorming

P.C. Schuur

WP 17 Coordinated planning of preventive maintenance in hierarchical production systems

G. van Dijkhuizen and $A$. van Harten

WP 18 Fuzzy group decision making in a competitive situation

J. Yan, A. van Harten, L. van der Wegen

WP 19 Existence of symmetric metaequilibria and their a-priori probability in metagames

J. Yan, A. van Harten, L. van der Wegen

WP 20 New circle coverings of an equilateral triangle

J.B.M. Melissen, P.C. Schuur, A. Heppes, Zs. Gaspar en T. Tarnai

WP 21 Evaluation of three control concepts for the use of recipe flexiblity in production planning

W.G.M.M. Rutten and J.W.M. Bertrand

WP 22 A taxonomy of systems of corporate governance 
Jeroen Weimer \& Joost C. Pape

WP 23 Bedrijfskunde en methodologie

Sander van Triest

WP 24 On the theoretical relation between operating leverage, earnings variability, and systematic risk

Sander van Triest \& Aswin Bartels

WP 25 Business care Roteb : recovery strategies for monitors

Harold Krikke

WP 26 The organisational and information aspects of the financial logistical management concept in theory and practice

D. Swagerman, A. Wassenaar

WP 27 Intercontinental airline flight schedule design

A. van Harten, P.D. Bootsma

WP $28 \quad$ An integrated approach to process control

Werner A.J. Schippers

WP 29 Inventory control in multi-echelon divergent systems with random lead times

M.C. van der Heijden, E.B. Diks en A.G. de Kok

WP $30 \quad$ Revolution through electronic purchasing

J. Telgen

WP 31 Over uitbesteding van voedingsverzorging in de zorgsector

A. van Harten, E.J. Braakman, D. Schuilenburg, J.P. Papenhuizen

WP 32 Dynamic scheduling of batch operations with non-identical machines

D.J. van der Zee, A. van Harten, P.C. Schuur

WP 33 Multi-echelon inventory control in divergent systems with shipping frequencies

M.C. van der Heijden

WP 34 A new magical lamp to rub? : the multiple constituency approach : a potentially useful framework for research on the organizational effectiveness construct

\section{J. Weimer, M. van Riemsdijk}

WP 35 Het bepalen van een recovery-strategie voor afgeslankte duurzame producten H.R. Krikke

WP 36 Integral organizational renewal : between structure and uncertainty F.M. van Eijnatten, L.A. Fitzgerald

WP 37 Inter-company supply chain planning : extending the current modeling perspective J. Fransoo, M. Wouters

WP 38 Zorginstellingen hebben behoefte aan hulp bij verbetering van de doelmatigheid J. Telgen

WP 39 Spare parts management at the Royal Netherlands Navy : vari-metric and beyond J.W. Rustenburg, G.J.J.A.N. van Houtum, W.H.M. Zijm

WP $40 \quad$ Evolution of ERP systems

J.C. Wortmann

WP 41 A queuing model for due date control in a multi server repair shop with subcontracting

J. Keizers, I. Adan, J. van der Wal

WP 42 Stocking strategy for service parts : a case study

R. Botter, L. Fortuin

WP 43 Coordinated production maintenance planning in airline flight schedule development G. van Dijkhuizen

WP 44 Warehouse design and control : framework and literature review

B. Rouwenhorst, R.J. Mantel, B. Reuter, V. Stockrahm, G.J. van Houtum, and

W.H.M. Zijm 